\begin{tabular}{|c|c|c|}
\hline decartesian & Jumal Matematika dan Aplikasi & \\
\hline & dedarcterial & \\
\hline$=-11 \mathrm{III}$ & $\begin{array}{c}\text { ISSN:2302-4224 } \\
\text { J o u r n a I h o m e p a g e: } \text { https://ejournal.unsrat.ac.id/index.php/decartesian }\end{array}$ & deCartesian \\
\hline
\end{tabular}

\title{
Optimasi Produksi Air Bersih Pelanggan PT. Air Manado Menggunakan Metode Goal Programming
}

\author{
Meyhard Sualang1, Nelson Nainggolan ${ }^{1}$, John S. Kekenusa ${ }^{*}$ \\ ${ }^{1}$ Program Studi Matematika-Fakultas Matematika dan Ilmu Pengetahuan Alam-Universitas Sam Ratulangi Manado, Indonesia \\ *Corresponding author: johnskekenusa@yahoo.com
}

\begin{abstract}
A B S T R A K
Air merupakan salah satu sumber daya alam yang sangat berperan penting untuk kebutuhan dasar sehari-hari, maka dibutuhkan air yang bermutu dan layak digunakan. PT Air Manado merupakan satu-satunya perusahaan untuk menyalurkan air bersih bagi penduduk Kota Manado dan sekitarnya, sehingga dalam memenuhi kebutuhan air bersih dengan batasan yang ada dalam perusahaan maka diperlukan metode dalam mengoptimalkan produksi air bersih. Penelitian ini bertujuan untuk mendapatkan hasil produksi air bersih yang optimal agar dapat memenuhi kebutuhan pelanggan dan memberikan keuntungan bagi perusahaan. Dengan menggunakan metode goal programming maka didapat hasil optimasi produksi air bersih di Instalasi Pengolahan Air (IPA) Paal dua sebesar $312.088,046 \mathrm{~m}^{3}$, IPA Lotta sebesar $142.663,903 \mathrm{~m}^{3}$, IPA Malalayang sebesar $77.053,136 \mathrm{~m}^{3}$, IPA Pancuran Sembilan sebesar $62.212,821 \mathrm{~m}^{3}$ dan IPA Koka sebesar $11.415,549 \mathrm{~m}^{3}$, dengan pendapatan penjualan air bersih sebesar Rp 4.239.479.087,00
\end{abstract}

$\begin{array}{ll}\text { INFO ARTIKEL } & \\ \text { Diterima } & : \text { 26 Februari } 2018 \\ \text { Diterima setelah revisi } & : \text { 9 Maret } 2018 \\ \text { Tersedia online } & : \text { 31 Maret } 2018\end{array}$

\section{Kata Kunci :}

Air

PT. Air Manado,

Optimasi,

Goal Programming.

\section{PENDAHULUAN}

Air merupakan salah satu sumber daya alam yang sangat berperan penting bagi makhluk hidup. Tanpa adanya air kelangsungan hidup dari makhluk hidup akan berakhir. Bagi manusia air diperlukan untuk kebutuhan dasar sehari-hari misalnya untuk: minum, mandi, memasak, mencuci, keperluan kebersihan lingkungan, dan sebagainya. Untuk memenuhi kebutuhan dasar tersebut maka manusia memerlukan air bersih, yaitu air yang bermutu dan layak digunakan.

Air tawar di bumi hanya 3\% dari total keseluruhan air, 97\% lainya adalah air laut dan dua per tiga dari 3\% air tawar merupakan bongkahan es di Kutub [1]. Berdasarkan laporan yang dikeluarkan direktorat Jendral Pengendalian Pencemaran dan Kerusakan Lingkungan Kementrian Lingkungan Hidup dan kehutanan (KLHK), hampir 68\% mutu air sungai di Indonesia dalam status tercemar [2]. Itu artinya hanya sebagian kecil saja air yang bisa langsung digunakan untuk kebutuhan manusia.

Menurut data BPS 2017, laju pertumbuhan penduduk Indonesia mencapai 1,36\% . Khususnya di Kota Manado jumlah penduduk tahun 2011 tercatat sebanyak 415.114 jiwa dan pada tahun 2016 tercatat sebanyak 427.906 jiwa [3]. Dengan semakin meningkatnya pertumbuhan penduduk maka semakin besar pula volume air yang diperlukan.

Perusahaan Daerah Air Minum (PDAM) merupakan salah satu unit usaha milik daerah yang bergerak dalam distribusi air bersih bagi masyarakat umum. PDAM terdapat di setiap Provinsi, Kabupaten, dan Kota di seluruh Indonesia. PDAM merupakan perusahaan daerah sebagai sarana penyedia air bersih yang diawasi dan dimonitori oleh aparat eksekutif maupun legislatif. Di Kota Manado, PT. Air Manado sebagai Perusahaan Daerah Air Minum yang memiliki hak monopoli atas air, untuk dimanfaatkan bagi kepentingan umum, maka PT. Air Manado harus mampu memenuhi kebutuhan air bersih bagi penduduk Kota Manado.

Untuk memenuhi kebutuhan air bersih bagi penduduk Kota Manado serta mendapatkan keuntungan pendapatan bagi perusahaan, maka diperlukan suatu metode dalam mengoptimalkan produksi air bersih. Salah satu metode dalam Operations Research yang dapat menyelesaikan masalah tersebut adalah metode goal programming. 
Metode goal programming merupakan suatu teknik dalam mengambil keputusan untuk menganalisis dan membuat solusi persoalan yang melibatkan banyak tujuan sehingga diperoleh hasil yang optimal [4].

Beberapa penelitian yang dilakukan sebelumnya adalah : optimasi pendistribusian raskin dengan menggunakan metode goal programming [5]. optimasi pendistribusian air menggunakan metode Least Cost dan metode Modified Distribution [6]. Menggunakan model fuzzy goal programming yang diselesaikan dengan linier programming pada perencanaan produksi [7].

Dalam penelitian ini akan dilakukan optimasi produksi air bersih dalam memenuhi kebutuhan pelanggan PT. Air Manado dengan keuntungan perusahaan maksimum menggunakan metode goal programming.

\section{GOAL PROGRAMMING}

Linear programming merupakan suatu teknik perencanaan yang bersifat analisis, yang analisisnya menggunakan model matematis, dengan tujuan menemukan beberapa kombinasi alternatif pemecahan optimum terhadap persoalan[8]. Goal programming adalah pengembangan dari linear programming dengan lebih dari satu fungsi tujuan.

Ide dasar dalam goal Programming adalah untuk menetapkan suatu tujuan yang dinyatakan dengan angka tertentu untuk setiap tujuan, merumuskan suatu fungsi tujuan untuk setiap tujuan dan kemudian mencari penyelesaian yang meminimumkan jumlah (tertimbang) dari penyimpangan-penyimpangan fungsi-fungsi tujuan terhadap tujuan masing-masing [9].

\subsection{Fungsi Tujuan Goal Programming}

Setiap model linear goal programming paling sedikit terdiri dari tiga fungsi tujuan yaitu [4].

$$
\text { Meminimumkan } Z=\sum_{i=1}^{m} d_{i}^{-}+d_{i}^{+}
$$

Fungsi tujuan ini digunakan jika variabel simpangan dalam suatu masalah tidak dibedakan menurut prioritas atau bobot.

$$
\text { Meminimumkan } Z=\sum_{i=1}^{m} P_{k}\left(d_{i}^{-}+d_{i}^{+}\right)
$$

Fungsi tujuan ini digunakan dalam suatu masalah dengan urutan tujuan diperlukan tetapi variabel simpangan didalam setiap tingkat prioritas memiliki kepentingan yang sama.

$$
\text { Meminimumkan } Z=\sum_{i=1}^{m} W_{k i} P_{k}\left(d_{i}^{-}+d_{i}^{+}\right)
$$

Fungsi tujuan ini, tujuan-tujuan diurutkan dan variabel simpangan pada setiap tingkat prioritas dibedakan dengan menggunkan bobot yang berlainan

\subsection{Fungsi Kendala}

Terdapat enam jenis kendala tujuan yang berlainan maksud setiap jenis kendala itu ditentukan oleh hubungannya dengan fungsi tujuan [10].

\begin{tabular}{|l|c|c|c|}
\hline $\begin{array}{c}\text { Kendala } \\
\text { Tujuan }\end{array}$ & $\begin{array}{c}\text { Variabel } \\
\text { Simpangan } \\
\text { dalam } \\
\text { fungsi } \\
\text { tujuan }\end{array}$ & $\begin{array}{c}\text { Kemungkinan } \\
\text { Simpangan }\end{array}$ & $\begin{array}{c}\text { Penggunaan } \\
\text { Nilai RHS } \\
\text { yang } \\
\text { diinginkan }\end{array}$ \\
\hline$a_{i j} x_{j}+d_{i}^{-}=b_{i}$ & $d_{i}^{-}$ & Negatif & $=b_{i}$ \\
\hline$a_{i j} x_{j}-d_{i}^{+}=b_{i}$ & $d_{i}^{+}$ & Positif & $=b_{i}$ \\
\hline $\begin{array}{l}a_{i j} x_{j}+d_{i}^{-}-d_{i}^{+} \\
=b_{i}\end{array}$ & $d_{i}^{-}$ & $\begin{array}{c}\text { Negatif dan } \\
\text { Positif }\end{array}$ & $b_{i}$ atau lebih \\
\hline $\begin{array}{l}a_{i j} x_{j}+d_{i}^{-}-d_{i}^{+} \\
=b_{i}\end{array}$ & $d_{i}^{+}$ & $\begin{array}{c}\text { Negatif dan } \\
\text { Positif }\end{array}$ & $b_{i}$ atau kurang \\
\hline $\begin{array}{l}a_{i j} x_{j}+d_{i}^{-}-d_{i}^{+} \\
=b_{i}\end{array}$ & $d_{i}^{-}$dan $d_{i}^{+}$ & $\begin{array}{c}\text { Negatif dan } \\
\text { Positif }\end{array}$ & $=b_{i}$ \\
\hline$a_{i j} x_{j}-d_{i}^{+}=b_{i}$ & $d_{i}^{+}($art $f)$ & Tidak ada & $=b_{i}$ \\
\hline
\end{tabular}

\section{METODOLOGI PENELITIAN}

\subsection{Waktu dan tempat Penelitian}

Penelitian ini dilaksanakan selama empat bulan pada bulan oktober 2017 sampai Januari 2018. Pengambilan data dilaksanakan di Finance \& Acounting Departemen PT Air Manado, dan analisis data dilaksanakan di Jurusan Matematika FMIPA Unsrat.

\subsection{Tahapan Penelitian \\ - Pengumpulan Data \\ - Pengolahan Data \\ - Memformulasikan Model Goal Programming \\ - Mendapatkan Hasil Optimasi Goal Programming}

\section{HASIL DAN PEMBAHASAN}

Data yang dibutuhkan untuk pembentukan model goal programming dalam mengoptimalkan produksi air bersih

\begin{tabular}{|c|c|c|c|c|c|}
\hline \multirow[b]{2}{*}{ Jenis Pelanggan } & \multicolumn{5}{|c|}{ IPA } \\
\hline & Paal Dua & Lotta & Malalay ang & \begin{tabular}{|l|} 
Pancuran \\
Sembilan
\end{tabular} & Koka \\
\hline Rumah Sederhana & 209394,106 & 125578,482 & 49542,056 & 57852,752 & 10726,596 \\
\hline Tempat Ibadah & 3538,464 & 1668,544 & 546,592 & 747,968 & 201,376 \\
\hline Sekolah & 863,170 & 249,865 & 113,575 & 204,435 & 68,145 \\
\hline $\begin{array}{l}\text { Panti Asuhan \& } \\
\text { Yay asan Sosial } \\
\end{array}$ & 608,080 & 386,960 & 221,120 & 138,200 & 27,640 \\
\hline $\begin{array}{l}\text { Instansi Pemerintah \& } \\
\text { ABRI tingkat Provinsi/ } \\
\text { Pusat }\end{array}$ & 12929,136 & 6072,776 & 6464,568 & 1371,272 & 391,792 \\
\hline $\begin{array}{l}\text { Instansi Pemerintah \& } \\
\text { ABRI tingkat } \\
\text { Kecamatan/Kelurahan }\end{array}$ & 435,382 & 145,127 & 72,564 & 36,282 & \\
\hline $\begin{array}{l}\text { Hidran umum \& WC } \\
\text { Umum }\end{array}$ & 460,782 & 102,396 & 136,528 & 85,330 & \\
\hline Niaga Kecil & 43351,704 & 4727,448 & 15221,712 & 1944,624 & \\
\hline $\begin{array}{l}\text { Rumah Mewah \& } \\
\text { Industri Rumah Tangga }\end{array}$ & 1350,970 & 229,410 & 458,820 & 101,960 & \\
\hline Rumah Sakit & 410,998 & 1232,994 & 1643,992 & & \\
\hline Industri \& Niaga besar & 20709,658 & 1373,016 & 2631,614 & & \\
\hline Kelompok Khusus & 379,278 & & & & \\
\hline
\end{tabular}

Tabel 1. Hasil Perhitungan Tingkat Permintaan Air Bersih Periode Mei $2018\left(\mathrm{~m}^{3}\right)$ 
Tabel 2. Hasil Perhitungan Batas Bawah Permintaan Air Bersih Periode Mei $2018\left(\mathrm{~m}^{3}\right)$

\begin{tabular}{|l|c|c|c|c|c|}
\hline \multirow{2}{*}{ Jenis Pelanggan } & \multicolumn{5}{|c|}{ IPA } \\
\cline { 2 - 6 } & Paal Dua & Lotta & Malalay ang & $\begin{array}{c}\text { Pancuran } \\
\text { Sembilan }\end{array}$ & Koka \\
\hline Rumah Sederhana & 187328,887 & 112345,460 & 44321,487 & 51756,431 & 9596,265 \\
\hline Tempat Ibadah & 2912,270 & 1373,265 & 449,863 & 615,602 & 165,739 \\
\hline Sekolah & 598,500 & 173,250 & 78,750 & 141,750 & 47,250 \\
\hline $\begin{array}{l}\text { Panti Asuhan \& } \\
\text { Yay asan Sosial }\end{array}$ & 452,510 & 287,961 & 164,549 & 102,843 & 20,569 \\
\hline $\begin{array}{l}\text { Instansi Pemerintah \& } \\
\text { ABRI tingkat Provinsi/ } \\
\text { Pusat }\end{array}$ & 10682,806 & 5017,682 & 5341,403 & 1133,025 & 323,721 \\
\hline $\begin{array}{l}\text { Instansi Pemerintah \& } \\
\text { ABRI tingkat } \\
\text { Kecamatan/Kelurahan }\end{array}$ & 312,316 & 104,105 & 52,053 & 26,026 & \\
\hline $\begin{array}{l}\text { Hidran umum \& WC } \\
\text { Umum }\end{array}$ & 378,000 & 84,000 & 112,000 & 70,000 & \\
\hline Niaga Kecil & 39111,081 & 4265,013 & 13732,738 & 1754,403 & \\
\hline $\begin{array}{l}\text { Rumah Mewah \& } \\
\text { Industri Rumah Tangga }\end{array}$ & 1190,041 & 202,082 & 404,165 & 89,814 & \\
\hline Rumah Sakit & 232,818 & 698,455 & 931,273 & & \\
\hline Industri \& Niaga besar & 12093,268 & 801,764 & 1536,714 & & \\
\hline Kelompok Khusus & 320,000 & & & & \\
\hline
\end{tabular}

Tabel 3. Hasil Perhitungan Batas Atas Permintaan Air Bersih Periode Mei $2018\left(\mathrm{~m}^{3}\right)$

\begin{tabular}{|l|c|c|c|c|c|}
\hline \multirow{2}{*}{ Jenis Pelanggan } & \multicolumn{5}{|c|}{ IPA } \\
\cline { 2 - 6 } & Paal Dua & Lotta & Malalay ang & $\begin{array}{c}\text { Pancuran } \\
\text { Sembilan }\end{array}$ & Koka \\
\hline Rumah Sederhana & 235224,253 & 141069,418 & 55653,396 & 64989,271 & 12049,793 \\
\hline Tempat Ibadah & 4279,965 & 2018,195 & 661,133 & 904,708 & 243,575 \\
\hline Sekolah & 1293,900 & 374,550 & 170,250 & 306,450 & 102,150 \\
\hline $\begin{array}{l}\text { Panti Asuhan \& } \\
\text { Yay asan Sosial }\end{array}$ & 838,538 & 533,615 & 304,923 & 190,577 & 38,115 \\
\hline $\begin{array}{l}\text { Instansi Pemerintah \& } \\
\text { ABRI tingkat Provinsi/ } \\
\text { Pusat }\end{array}$ & 16031,117 & 7529,767 & 8015,558 & 1700,270 & 485,791 \\
\hline $\begin{array}{l}\text { Instansi Pemerintah \& } \\
\text { ABRI tingkat } \\
\text { Kecamatan/Kelurahan }\end{array}$ & 638,769 & 212,923 & 106,462 & 53,231 & \\
\hline $\begin{array}{l}\text { Hidran umum \& WC } \\
\text { Umum }\end{array}$ & 618,300 & 137,400 & 183,200 & 114,500 & \\
\hline Niaga Kecil & 51016,017 & 5563,232 & 17912,816 & 2288,421 & \\
\hline $\begin{array}{l}\text { Rumah Mewah \& } \\
\text { Industri Rumah Tangga }\end{array}$ & 1497,674 & 254,322 & 508,644 & 113,032 & \\
\hline Rumah Sakit & 649,111 & 1947,333 & 2596,444 & & \\
\hline Industri \& Niaga besar & 38298,106 & 2539,101 & 4866,610 & & \\
\hline Kelompok Khusus & 444,000 & & & & \\
\hline
\end{tabular}

Tabel 4. Kapasitas Produksi Air Bersih di PT Air Manado Instalasi Pengolahan Air $\quad$ Kapasitas

\begin{tabular}{|l|c|c|}
\multirow{2}{*}{\begin{tabular}{c} 
Instalasi Pengolahan Air \\
\cline { 2 - 3 }
\end{tabular}} & $\mathrm{l} / \mathrm{dt}$ & $\mathrm{m}^{3} / \mathrm{bln}$ \\
\hline Paal Dua & 375 & 972.000 \\
\hline Lotta & 150 & 388.800 \\
\hline Malalayang & 120 & 311.040 \\
\hline Pancuran Sembilan & 34 & 88.128 \\
\hline Koka & 20 & 51.840 \\
\hline
\end{tabular}

Tabel 5. Hasil Prediksi Pendapatan Penjualan Air Bersih

\begin{tabular}{|c|c|}
\hline Periode & Pendapatan (Rp) \\
\hline Jan-18 & 4.177 .466 .960 \\
\hline Feb-18 & 4.192 .969 .992 \\
\hline Mar-18 & 4.208 .473 .023 \\
\hline Apr-18 & 4.223 .976 .055 \\
\hline May-18 & 4.239 .479 .087 \\
\hline Jun-18 & 4.254 .982 .118 \\
\hline Jul-18 & 4.270 .485 .150 \\
\hline Aug-18 & 4.285 .988 .182 \\
\hline Sep-18 & 4.301 .491 .213 \\
\hline Oct-18 & 4.316 .994 .245 \\
\hline Nov-18 & $4.332 . .497 .277$ \\
\hline Dec-18 & 4.348 .000 .308 \\
\hline
\end{tabular}

4.1. Formulasi Model Goal Programming

4.1.1. Variabel Keputusan

$\boldsymbol{x}_{A j}=$ Jumlah produksi air bersih di IPA Paal dua dengan jenis pelanggan , untuk $j=1,2, \ldots, 12$

$x_{B j}=$ Jumlah produksi air bersih di IPA Lotta dengan jenis pelanggan , untuk $j=1,2, \ldots, 11$

$x_{C j}=$ Jumlah produksi air bersih di IPA Malalayang dengan jenis pelanggan , untuk $j=1,2, \ldots, 11$

$x_{D j}=$ Jumlah produksi air bersih di IPA Pancuran Sembilan dengan jenis pelanggan $j=1,2, \ldots, 9$

$x_{E j}=$ Jumlah produksi air bersih di IPA Koka dengan jenis pelanggan , untuk $j=1,2, \ldots, 5$

\subsubsection{Fungsi Kendala}

1. Kendala tingkat permintaan air bersih di IPA Paal Dua

$$
\begin{aligned}
& x_{A 1}+d_{1}^{-}-d_{1}^{+}=209394,106 \\
& x_{A 2}+d_{2}^{-}-d_{2}^{+}=3538,464 \\
& x_{A 3}+d_{3}^{-}-d_{3}^{+}=863,170 \\
& x_{A 4}+d_{4}^{-}-d_{4}^{+}=608,080 \\
& x_{A 5}+d_{5}^{-}-d_{5}^{+}=12929,136 \\
& x_{A 6}+d_{6}^{-}-d_{6}^{+}=435,382 \\
& x_{A 7}+d_{7}^{-}-d_{7}^{+}=460,782 \\
& x_{A 8}+d_{8}^{-}-d_{8}^{+}=43351,704 \\
& x_{A 9}+d_{9}^{-}-d_{9}^{+}=1350,970 \\
& x_{A 10}+d_{10}^{-}-d_{10}^{+}=410,998 \\
& x_{A 11}+d_{11}^{-}-d_{11}^{+}=20709,658 \\
& x_{A 12}+d_{12}^{-}-d_{12}^{+}=379,278
\end{aligned}
$$

2. Kendala tingkat permintaan air bersih di IPA Lotta

$$
\begin{aligned}
& x_{B 1}+d_{13}^{-}-d_{13}^{+}=125578,482 \\
& x_{B 2}+d_{14}^{-}-d_{14}^{+}=1668,544 \\
& x_{B 3}+d_{15}^{-}-d_{15}^{+}=249,865 \\
& x_{B 4}+d_{16}^{-}-d_{16}^{+}=386,960 \\
& x_{B 5}+d_{17}^{-}-d_{17}^{+}=6072,776 \\
& x_{B 6}+d_{18}^{-}-d_{18}^{+}=145,127 \\
& x_{B 7}+d_{19}^{-}-d_{19}^{+}=102,396 \\
& x_{B 8}+d_{20}^{-}-d_{20}^{+}=4727,448 \\
& x_{B 9}+d_{21}^{-}-d_{21}^{+}=229,410 \\
& x_{B 10}+d_{22}^{-}-d_{22}^{+}=1232,994 \\
& x_{B 11}+d_{23}^{-}-d_{23}^{+}=1373,016
\end{aligned}
$$

3. Kendala tingkat permintaan air bersih di IPA Malalayang

$$
\begin{aligned}
& x_{C 1}+d_{24}^{-}-d_{24}^{+}=49542,056 \\
& x_{C 2}+d_{25}^{-}-d_{25}^{+}=546,592 \\
& x_{C 3}+d_{26}^{-}-d_{26}^{+}=113,575 \\
& x_{C 4}+d_{27}^{-}-d_{27}^{+}=221,120 \\
& x_{C 5}+d_{28}^{-}-d_{28}^{+}=6464,568 \\
& x_{C 6}+d_{29}^{-}-d_{29}^{+}=72,564 \\
& x_{C 7}+d_{30}^{-}-d_{30}^{+}=136,528 \\
& x_{C 8}+d_{31}^{-}-d_{31}^{+}=15221,712 \\
& x_{C 9}+d_{32}^{-}-d_{32}^{+}=458,820 \\
& x_{C 10}+d_{33}^{-}-d_{33}^{+}=1643,992 \\
& x_{C 11}+d_{34}^{-}-d_{34}^{+}=2631,614
\end{aligned}
$$

4. Kendala tingkat permintaan air bersih di IPA Pancuran Sembilan

$$
\begin{aligned}
& x_{D 1}+d_{35}^{-}-d_{35}^{+}=57852,752 \\
& x_{D 2}+d_{36}^{-}-d_{36}^{+}=747,968 \\
& x_{D 3}+d_{37}^{-}-d_{37}^{+}=204,435 \\
& x_{D 4}+d_{38}^{-}-d_{38}^{+}=138,200 \\
& x_{D 5}+d_{39}^{-}-d_{39}^{+}=1371,272 \\
& x_{D 6}+d_{40}^{-}-d_{40}^{+}=36,282 \\
& x_{D 7}+d_{41}^{-}-d_{41}^{+}=85,330
\end{aligned}
$$


$x_{D 8}+d_{42}^{-}-d_{42}^{+}=1944,624$

$x_{D 9}+d_{43}^{-}-d_{43}^{+}=101,960$

5. Kendala tingkat permintaan air bersih di IPA Koka

$$
\begin{aligned}
& x_{E 1}+d_{44}^{-}-d_{4}^{+}=10726,596 \\
& x_{E 2}+d_{45}^{-}-d_{45}^{+}=201,376 \\
& x_{E 3}+d_{46}^{-}-d_{46}^{+}=68,145 \\
& x_{E 4}+d_{47}^{-}-d_{47}^{+}=27,640 \\
& x_{E 5}+d_{48}^{-}-d_{48}^{+}=391,792
\end{aligned}
$$

6. Kendala batas bawah permintaan air bersih di IPA Paal Dua

$$
\begin{aligned}
& x_{A 1}+d_{49}^{-}-d_{49}^{+}=187328,887 \\
& x_{A 2}+d_{50}^{-}-d_{50}^{+}=2912,270 \\
& x_{A 3}+d_{51}^{-}-d_{51}^{+}=598,500 \\
& x_{A 4}+d_{52}^{-}-d_{52}^{+}=452,510 \\
& x_{A 5}+d_{53}^{-}-d_{53}^{+}=10682,806 \\
& x_{A 6}+d_{54}^{-}-d_{54}^{+}=312,316 \\
& x_{A 7}+d_{55}^{-}-d_{55}^{+}=378,000 \\
& x_{A 8}+d_{56}^{-}-d_{56}^{+}=39111,081 \\
& x_{A 9}+d_{57}^{-}-d_{57}^{+}=1190,041 \\
& x_{A 10}+d_{58}^{-}-d_{58}^{+}=232,818 \\
& x_{A 11}+d_{59}^{-}-d_{59}^{+}=12093,268 \\
& x_{A 12}+d_{60}^{-}-d_{60}^{+}=320,000
\end{aligned}
$$

7. Kendala batas bawah permintaan air bersih di IPA Lotta

$$
\begin{aligned}
& x_{B 1}+d_{61}^{-}-d_{61}^{+}=112345,460 \\
& x_{B 2}+d_{62}^{-}-d_{62}^{+}=1373,265 \\
& x_{B 3}+d_{63}^{-}-d_{63}^{+}=173,250 \\
& x_{B 4}+d_{64}^{-}-d_{64}^{+}=287,961 \\
& x_{B 5}+d_{65}^{-}-d_{65}^{+}=5017,682 \\
& x_{B 6}+d_{66}^{-}-d_{66}^{+}=104,105 \\
& x_{B 7}+d_{67}^{-}-d_{67}^{+}=84,000 \\
& x_{B 8}+d_{68}^{-}-d_{68}^{+}=4265,013 \\
& x_{B 9}+d_{69}^{-}-d_{69}^{+}=202,082 \\
& x_{B 10}+d_{70}^{-}-d_{70}^{+}=698,455 \\
& x_{B 11}+d_{71}^{-}-d_{71}^{+}=801,764
\end{aligned}
$$

8. Kendala batas bawah permintaan air bersih di IPA Malalayang

$$
\begin{aligned}
& x_{C 1}+d_{72}^{-}-d_{72}^{+}=44321,487 \\
& x_{C 2}+d_{73}^{-}-d_{73}^{+}=449,863 \\
& x_{C 3}+d_{74}^{-}-d_{74}^{+}=78,750 \\
& x_{C 4}+d_{75}^{-}-d_{75}^{+}=164,549 \\
& x_{C 5}+d_{76}^{-}-d_{76}^{+}=5341,403 \\
& x_{C 6}+d_{77}^{-}-d_{77}^{+}=52,053 \\
& x_{C 7}+d_{78}^{-}-d_{78}^{+}=112,000 \\
& x_{C 8}+d_{79}^{-}-d_{79}^{+}=13732,738 \\
& x_{C 9}+d_{80}^{-}-d_{80}^{+}=404,165 \\
& x_{C 10}+d_{81}^{-}-d_{81}^{+}=931,273 \\
& x_{C 11}+d_{82}^{-}-d_{82}^{+}=1536,714
\end{aligned}
$$

9. Kendala batas bawah permintaan air bersih di IPA Pancuran Sembilan

$$
\begin{aligned}
& x_{D 1}+d_{83}^{-}-d_{83}^{+}=51756,431 \\
& x_{D 2}+d_{84}^{-}-d_{84}^{+}=615,602 \\
& x_{D 3}+d_{85}^{-}-d_{85}^{+}=141,750 \\
& x_{D 4}+d_{86}^{-}-d_{86}^{+}=102,843 \\
& x_{D 5}+d_{87}^{-}-d_{87}^{+}=1133,025 \\
& x_{D 6}+d_{88}^{-}-d_{88}^{+}=26,026 \\
& x_{D 7}+d_{89}^{-}-d_{89}^{+}=70,000 \\
& x_{D 8}+d_{90}^{-}-d_{90}^{+}=1754,403 \\
& x_{D 9}+d_{91}^{-}-d_{91}^{+}=89,814
\end{aligned}
$$

10. Kendala batas bawah permintaan air bersih di IPA Koka

$$
\begin{aligned}
& x_{E 1}+d_{92}^{-}-d_{92}^{+}=9596,265 \\
& x_{E 2}+d_{93}^{-}-d_{93}^{+}=165,739 \\
& x_{E 3}+d_{94}^{-}-d_{94}^{+}=47,250 \\
& x_{E 4}+d_{95}^{-}-d_{95}^{+}=20,569 \\
& x_{E 5}+d_{96}^{-}-d_{96}^{+}=323,721
\end{aligned}
$$

11. Kendala batas atas permintaan air bersih di IPA Paal Dua

$$
\begin{aligned}
& x_{A 1}+d_{97}^{-}-d_{97}^{+}=235224,253 \\
& x_{A 2}+d_{98}^{-}-d_{98}^{+}=4279,965 \\
& x_{A 3}+d_{99}^{-}-d_{99}^{+}=1293,900 \\
& x_{A 4}+d_{100}^{-}-d_{100}^{+}=838,538 \\
& x_{A 5}+d_{101}^{-}-d_{101}^{+}=16031,117 \\
& x_{A 6}+d_{102}^{-}-d_{102}^{+}=638,769 \\
& x_{A 7}+d_{103}^{-}-d_{103}^{+}=618,300 \\
& x_{A 8}+d_{104}^{-}-d_{104}^{+}=51016,017 \\
& x_{A 9}+d_{105}^{-}-d_{105}^{+}=1497,674 \\
& x_{A 10}+d_{106}^{-}-d_{106}^{+}=649,111 \\
& x_{A 11}+d_{107}^{-}-d_{107}^{+}=38298,106 \\
& x_{A 12}+d_{108}^{-}-d_{108}^{+}=444,000
\end{aligned}
$$

12. Kendala batas atas permintaan air bersih di IPA Lotta

$$
\begin{aligned}
& x_{B 1}+d_{109}^{-}-d_{109}^{+}=141069,418 \\
& x_{B 2}+d_{110}^{-}-d_{110}^{+}=2018,195 \\
& x_{B 3}+d_{111}^{-}-d_{111}^{+}=374,550 \\
& x_{B 4}+d_{112}^{-}-d_{112}^{+}=533,615 \\
& x_{B 5}+d_{113}^{-}-d_{113}^{+}=7529,767 \\
& x_{B 6}+d_{114}^{-}-d_{114}^{+}=212,923 \\
& x_{B 7}+d_{115}^{-}-d_{115}^{+}=137,400 \\
& x_{B 8}+d_{116}^{-}-d_{116}^{+}=5563,232 \\
& x_{B 9}+d_{117}^{-}-d_{117}^{+}=254,322 \\
& x_{B 10}+d_{118}^{-}-d_{118}^{+}=1947,333 \\
& x_{B 11}+d_{119}^{-}-d_{119}^{+}=2539,101
\end{aligned}
$$

13. Kendala batas atas permintaan air bersih di IPA Malalayang

$$
\begin{aligned}
& x_{C 1}+d_{120}^{-}-d_{120}^{+}=55653,396 \\
& x_{C 2}+d_{121}^{-}-d_{121}^{+}=661,133 \\
& x_{C 3}+d_{122}^{-}-d_{122}^{+}=170,250 \\
& x_{C 4}+d_{123}^{-}-d_{123}^{+}=304,923 \\
& x_{C 5}+d_{124}^{-}-d_{124}^{+}=8015,558 \\
& x_{C 6}+d_{125}^{-}-d_{125}^{+}=106,462 \\
& x_{C 7}+d_{126}^{-}-d_{126}^{+}=183,200 \\
& x_{C 8}+d_{127}^{-}-d_{127}^{+}=17912,816 \\
& x_{C 9}+d_{128}^{-}-d_{128}^{+}=508,644 \\
& x_{C 10}+d_{129}^{-}-d_{129}^{+}=2596,444 \\
& x_{C 11}+d_{130}^{-}-d_{130}^{+}=4866,610
\end{aligned}
$$

14. Kendala batas atas permintaan air bersih di IPA Pancuran Sembilan

$$
\begin{aligned}
& x_{D 1}+d_{131}^{-}-d_{131}^{+}=64989,271 \\
& x_{D 2}+d_{132}^{-}-d_{132}^{+}=904,708 \\
& x_{D 3}+d_{133}^{-}-d_{133}^{+}=306,450 \\
& x_{D 4}+d_{134}^{-}-d_{134}^{+}=190,577 \\
& x_{D 5}+d_{135}^{-}-d_{135}^{+}=1700,270 \\
& x_{D 6}+d_{136}^{-}-d_{136}^{+}=53,231 \\
& x_{D 7}+d_{137}^{-}-d_{137}^{+}=114,500 \\
& x_{D 8}+d_{138}^{-}-d_{138}^{+}=2288,421 \\
& x_{D 9}+d_{139}^{-}-d_{139}^{+}=113,032
\end{aligned}
$$

15. Kendala batas atas permintaan air bersih di IPA Koka

$$
\begin{aligned}
& x_{E 1}+d_{140}^{-}-d_{140}^{+}=12049,793 \\
& x_{E 2}+d_{141}^{-}-d_{141}^{+}=243,575 \\
& x_{E 3}+d_{142}^{-}-d_{142}^{+}=102,150 \\
& x_{E 4}+d_{143}^{-}-d_{143}^{+}=38,115
\end{aligned}
$$


$x_{E 5}+d_{144}^{-}-d_{144}^{+}=485,791$

16. Kendala kapasitas produksi

$$
\begin{aligned}
& x_{A 1}+x_{A 2}+x_{A 3}+x_{A 4}+x_{A 5}+x_{A 6}+x_{A 7} \\
& +x_{A 8}+x_{A 9}+x_{A 10}+x_{A 11}+x_{A 12}+d_{145}^{-} \\
& -d_{145}^{+}=972000 \\
& x_{B 1}+x_{B 2}+x_{B 3}+x_{B 4}+x_{B 5}+x_{B 6}+x_{B 7} \\
& +x_{B 8}+x_{B 9}+x_{B 10}+x_{B 11}+d_{146}^{-}-d_{146}^{+} \\
& =388800 \\
& x_{C 1}+x_{C 2}+x_{C 3}+x_{C 4}+x_{C 5}+x_{C 6}+x_{C 7} \\
& +x_{C 8}+x_{C 9}+x_{C 10}+x_{C 11}+d_{147}^{-}-d_{147}^{+} \\
& =311040 \\
& x_{D 1}+x_{D 2}+x_{D 3}+x_{D 4}+x_{D 5}+x_{D 6}+x_{D 7} \\
& +x_{D 8}+x_{D 9}+d_{148}^{-}-d_{148}^{+}=88128 \\
& x_{E 1}+x_{E 2}+x_{E 3}+x_{E 4}+x_{E 5}+d_{149}^{-}-d_{149}^{+} \\
& =51840
\end{aligned}
$$

17. Kendala pendapatan penjualan air bersih $6056 x_{A 1}+5526 x_{A 2}+6737 x_{A 3}+6132 x_{A 4}$ $+8024 x_{A 5}+7418 x_{A 6}+4391 x_{A 7}+8629 x_{A 8}$ $+10446 x_{A 9}+8024 x_{A 10}+13759 x_{A 11}$ $+15140 x_{A 12}+6056 x_{B 1}+5526 x_{B 2}+6737 x_{B 3}$ $+6132 x_{B 4}+8024 x_{B 5}+7418 x_{B 6}+4391 x_{B 7}$ $+8629 x_{B 8}+10446 x_{B 9}+8024 x_{B 10}+13759 x_{B 11}$ $+6056 x_{C 1}+5526 x_{C 2}+6737 x_{C 3}+6132 x_{C 4}$ $+8024 x_{C 5}+7418 x_{C 6}+4391 x_{C 7}+8629 x_{C 8}$ $+10446 x_{C 9}+8024 x_{C 10}+13759 x_{C 11}$ $+6056 x_{D 1}+5526 x_{D 2}+6737 x_{D 3}+6132 x_{D 4}$ $+8024 x_{D 5}+7418 x_{D 6}+4391 x_{D 7}+8629 x_{D 8}$

$+10446 x_{D 9}+6056 x_{E 1}+5526 x_{E 2}$ $+6737 x_{E 3}+6132 x_{E 4}+8024 x_{E 5}+d_{150}^{-}$ $-d_{150}^{+}=4239479087$

\subsubsection{Fungsi Tujuan}

$$
\begin{aligned}
\operatorname{Min} Z= & \left(\sum_{j=1}^{48}\left(d_{j}^{-}+d_{j}^{+}\right)\right)+\left(\sum_{k=49}^{96}\left(d_{k}^{-}\right)\right)+\left(\sum_{l=97}^{144}\left(d_{l}^{+}\right)\right) \\
& +\left(\sum_{m=145}^{149}\left(d_{m}^{+}\right)\right)+d_{150}^{-}
\end{aligned}
$$

\subsubsection{Hasil Optimasi Goal Programming}

Tabel. 6 Solusi Optimal Jumlah Produksi Air Bersih

\begin{tabular}{|c|c|c|c|c|c|}
\hline $\begin{array}{c}\text { Variabel } \\
\text { Keputusan }\end{array}$ & $\begin{array}{c}\text { Jumlah } \\
\text { Produksi } \\
\text { Air Bersih } \\
\left(\mathrm{m}^{3}\right)\end{array}$ & $\begin{array}{c}\text { Variabel } \\
\text { Keputusan }\end{array}$ & $\begin{array}{c}\text { Jumlah } \\
\text { Produksi } \\
\text { Air Bersih } \\
\left(\mathrm{m}^{3}\right)\end{array}$ & $\begin{array}{c}\text { Variabel } \\
\text { Keputusan }\end{array}$ & $\begin{array}{c}\text { Jumlah } \\
\text { Produksi } \\
\text { Air Bersih } \\
\left(\mathrm{m}^{3}\right)\end{array}$ \\
\hline$x_{A 1}$ & 209394,109 & $x_{B 5}$ & 6072,776 & $x_{C 10}$ & 1643,992 \\
\hline$x_{A 2}$ & 3538,464 & $x_{B 6}$ & 145,127 & $x_{C 11}$ & 2631,614 \\
\hline$x_{A 3}$ & 866,320 & $x_{B 7}$ & 102,396 & $x_{D 1}$ & 57582,750 \\
\hline$x_{A 4}$ & 608,080 & $x_{B 8}$ & 4727,448 & $x_{D 2}$ & 747,968 \\
\hline$x_{A 5}$ & 12929,136 & $x_{B 9}$ & 229,410 & $x_{D 3}$ & 204,435 \\
\hline$x_{A 6}$ & 435,382 & $x_{B 10}$ & 1232,994 & $x_{D 4}$ & 138,200 \\
\hline$x_{A 7}$ & 460,782 & $x_{B 11}$ & 2269,665 & $x_{D 5}$ & 1371,272 \\
\hline$x_{A 8}$ & 43351,699 & $x_{C 1}$ & 49542,051 & $x_{D 6}$ & 36,282 \\
\hline$x_{A 9}$ & 1350,970 & $x_{C 2}$ & 546,592 & $x_{D 7}$ & 85,330 \\
\hline$x_{A 10}$ & 410,998 & $x_{C 3}$ & 113,575 & $x_{D 8}$ & 1944,624 \\
\hline$x_{A 11}$ & 38298,105 & $x_{C 4}$ & 221,120 & $x_{D 9}$ & 101,960 \\
\hline$x_{A 12}$ & 444,000 & $x_{C 5}$ & 6464,568 & $x_{E 1}$ & 10726,596 \\
\hline$x_{B 1}$ & 125578,477 & $x_{C 6}$ & 72,564 & $x_{E 2}$ & 201,376 \\
\hline$x_{B 2}$ & 1668,544 & $x_{C 7}$ & 136,528 & $x_{E 3}$ & 68,145 \\
\hline$x_{B 3}$ & 249,865 & $x_{C 8}$ & 15221,712 & $x_{E 4}$ & 27,640 \\
\hline$x_{B 4}$ & 386,960 & $x_{C 9}$ & 458,820 & $x_{E 5}$ & 391,792 \\
\hline
\end{tabular}

Berdasarkan tabel 6 dapat diketahui optimasi produksi masing-masing Instalasi Pengolahan Air (IPA) di PT Air Manado sebagai berikut : a. Produksi air bersih di IPA Paal dua

$x_{A 1}+x_{A 2}+x_{A 3}+x_{A 4}+x_{A 5}+x_{A 6}+x_{A 7}+x_{A 8}$ $+x_{A 9}+x_{A 10}+x_{A 11}+x_{A 12}=312088,046 \mathrm{~m}^{3}$

b. Produksi air bersih di IPA Lotta $x_{B 1}+x_{B 2}+x_{B 3}+x_{B 4}+x_{B 5}+x_{B 6}+x_{B 7}+x_{B 8}$ $+x_{B 9}+x_{B 10}+x_{B 11}=142663,662 \mathrm{~m}^{3}$

c. Produksi air bersih di IPA Malalayang $x_{C 1}+x_{C 2}+x_{C 3}+x_{C 4}+x_{C 5}+x_{C 6}+x_{C 7}+x_{C 8}$ $+x_{C 9}+x_{C 10}+x_{C 11}=77053,136 \mathrm{~m}^{3}$

d. Produksi air bersih di IPA Pancuran Sembilan $x_{D 1}+x_{D 2}+x_{D 3}+x_{D 4}+x_{D 5}+x_{D 6}+x_{D 7}+x_{D 8}$ $+x_{D 9}=62212,821 \mathrm{~m}^{3}$

e. Produksi air bersih di IPA Koka $x_{E 1}+x_{E 2}+x_{E 3}+x_{E 4}+x_{E 5}=11415,549 \mathrm{~m}^{3}$

\subsubsection{Variabel Simpangan}

Hasil penelitian menunjukan sasaran memenuhi tingkat permintaan air bersih dengan simpangan negatif $d_{1}^{-}$sampai $d_{48}^{-}$bernilai nol, artinya hasil optimasi produksi memenuhi tingkat permintaan. Variabel simpangan negatif $d_{49}^{-}$sampai $d_{72}^{-}$bernilai nol dan variabel simpangan positif $d_{49}^{+}$sampai $d_{96}^{+}$bernilai lebih dari nol. Hal ini menjelaskan bahwa hasil optimasi produksi air bersih masih di atas batas bawah tingkat permintaan. Sehingga tujuan memaksimalkan batas bawah permintaan air bersih tercapai. Variabel simpangan positif $d_{97}^{+}$sampai $d_{144}^{+}$bernilai nol, artinya hasil optimasi produksi air bersih tidak melebihi batas atas permintaan, sehingga tujuan untuk meminimumkan kelebihan batas atas permintaan tercapai. Variabel simpangan positif $d_{145}^{+}$sampai $d_{149}^{+}$ bernilai nol, itu artinya hasil optimasi tidak melebihi kapasitas produksi, sehingga tujuan untuk meminimumkan kelebihan kapasitas produksi tercapai. Variabel simpangan $d_{150}^{+}$dan $d_{150}^{-}$bernilai nol. Hal ini menjelaskan bahwa sasaran untuk memaksimalkan pendapatan perusahaan tercapai, dengan pendapatan perusahaan sebesar Rp. 4.239.479.087

\section{KESIMPULAN}

Berdasarkan hasil penelitian disimpulkan bahwa optimasi : jumlah produksi air bersih di IPA Paal dua sebesar 312088,046 $\mathrm{m}^{3}$, jumlah produksi air bersih di IPA Lotta sebesar 142663,662 $\mathrm{m}^{3}$, jumlah produksi air bersih di IPA Malalayang sebesar 77053,136 $\mathrm{m}^{3}$, jumlah produksi air bersih di IPA Pancuran Sembilan sebesar $62212,821 \mathrm{~m}^{3}$, jumlah produksi air bersih di IPA Koka sebesar $11415,549 \mathrm{~m}^{3}$, dengan pendapatan perusahaan sebesar Rp. 4.239.479.087. Hasil optimasi produksi air bersih tidak melebihi kapasitas produksi yang tersedia di masing-masing Instalasi Pengolahan Air dan mampu memenuhi tingkat permintaan pelanggan PT Air Manado

\section{DAFTAR PUSTAKA}

[1] WWF. 2012. Air Bersih dan Kehidupan Manusia. https://www.wwf.or.id/?26120/Air-Bersih-danKehidupan-Manusia. [21 Januari 2018].

[2] National Geographic Indonesia. 2016. Air Sungai di Indonesia Tercemar Berat. http://nationalgeographic.co.id/berita/2016/05/ air-sungai-di-indonesia-tercemar-berat. $\quad$ [20 Januari 2018]. 
[3] BPS. 2017. Jumlah Penduduk Kota Manado Menurut Kecamatan dan Jenis Kelamin, 20112016.https://manadokota.bps.go.id/statictable/2 017/08/18/199/jumlah-penduduk-kota-manadomenurut-kecamatan-dan-jenis-kelamin-20112016.html. [28 November 2017].

[4] Rangkuti, A. 2013. 7 Model Riset Operasi \& Aplikasinya. Brilian Internasional. Surabaya.

[5] Raden, L., Y.A.R. Langi., dan T. Manurung. 2013. Optimasi Pendistribusian Raskin dengan Menggunakan Goal Programming. Jurnal MIPA UNSRAT 2(1) : 12-16.

[6] Nelwan, C., J.S. Kekenusa., dan Y. Langi. Optimasi Pendistribusian Air dengan Menggunakan Metode Least Cost dan metode Modified Distribution (Studi kasus : PDAM Kabupaten Minahasa Utara). Jurnal Ilmiah Sains 13(1) : 45-51

[7] Rindengan, A.J., P.T. Supriyo, A. Kustiyo. 2013. Model Fuzzy Goal Programming yang Diselesaikan dengan Linier Programming pada perencanaan produksi. DeCartesian 2(2) : 26-32

[8] Aminudin. 2005. Prinsip-prinsip Riset Operasi. Erlangga. Jakarta.

[9] Hillier, F., G. Lieberman., E. Gunawan., dan A. Mulia. 1994. Pengantar Riset Operasi (Jilid 1). Erlangga. Jakarta.

[10] Mulyono, S. 1991. Operations Research. FE-UI. Jakarta.

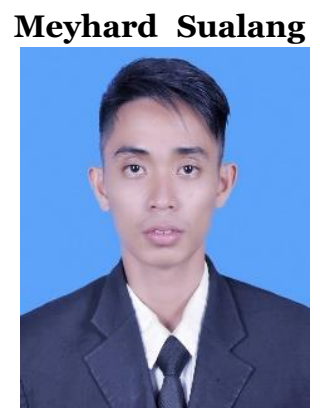

(meyhard.sualang@gmail.com) lahir dan tinggal di Desa Pangu, Kab. Minahasa Tenggara. Dia masih menempuh pendidikan tinggi di Program Studi Matematika, Fakultas Matematika dan Ilmu Pengetahuan Alam, Universitas Sam Ratulangi (UNSRAT) Manado. Tahun 2018 adalah tahun terakhir ia menempuh studi. Makalah ini merupakan hasil penelitian skripsinya yang dipublikasikan.

Nelson Nainggolan (n-nelson@unsrat.ac.id) lahir di

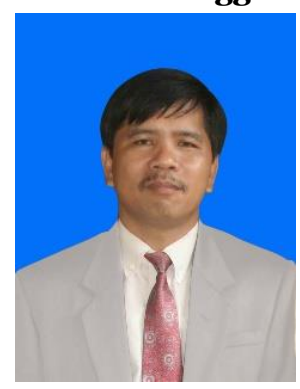
Tapanuli Utara tanggal 9 Maret 1967. Gelar sarjana pendidikan Matematika diperoleh tahun 1992 di FMIPA IKIP Negri Medan. Tahun 1996 menyelesaikan studi S2, di jurusan Matematika ITB Bandung. Tahun 2011 menyelesaikan studi S3 pada bidang Matematika di Universitas Padjadjaran Bandung. Saat ini menjadi pengajar akademik tetap di jurusan Matematika FMIPA Unsrat Manado.
John Socrates Kekenusa (johnskekenusa@yahoo.com)

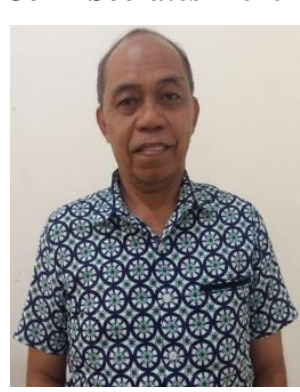
lahir di Tahuna (Sangihe), Sulawesi Utara 24 Agustus 1958. Pada tahun 1982 menyelesaikan pendidikan di Fakultas Perikanan UNSRAT Manado. Tahun 1988 menyelesaikan studi S-2 (Magister) pada program studi Statistika Terapan di IPB Bogor. Tahun 2003-2006 mengikuti pendidikan doktor (S-3) di

Universitas Airlangga Surabaya dalam bidang MIPA (penelitian bidang statistika tentang pemodelan) . Mulai 1 April 2007 diangkat menjadi Guru Besar Statistika pada Fakultas MIPA UNSRAT. ). Juga aktif meneliti, menulis, dan mengajar di jenjang S-1, S-2, dan S-3, dalam bidang statistika, filsafat ilmu, dan metodologi penelitian. 